\title{
KONSEP PENDIDIKAN AKHLAK DALAM AL-QUR'AN SURAH AL-MA'ARIJ AYAT 19-35 (KAJIAN TAFSIR AL-MARAGHI)
}

\author{
Lisna Ekawati, ${ }^{1}$ Ummu Sa'idah, ${ }^{2}$ Maimunah \\ ${ }^{1}$ Mahasiswa PAI FITK IAIN Ambon, ${ }^{2}$ Dosen PAI FITK IAIN Ambon
}

\begin{abstract}
Abstrak Tujuan peneliti mengkaji QS. al-Ma'arij ayat 19 sampai 35 berdasarkan tafsir al-Maraghi adalah untuk mengetahui kosep pendidikan akhlak menurut Ahmad Mushthafa (al-Maraghi). Jenis penelitian ini adalah penelitian kepustakaan (Library Research) dengan cara mencari, mengumpulkan, membaca bukubuku, dan menganalisis makna QS. Al-Ma'arij (70) Ayat 19 Sampai Ayat 35, dengan menggunakan kitab tafsir al-Maraghi. Serta lebih memfokuskan kepada konsep pendidikan akhlak itu sendiri. Hasil penelitian menunjukkan bahwa dalam surah al-Ma'arij ayat 19-35 terkandung. Konsep pendidikan akhlak, diantaranya: berpedoman atau berpegang teguh terhadap tauhid, al-qur'an dan hadist dan juga kita harus menjauhi sifat tercela yang umum dimiliki oleh manusia yaitu sifat keluh kesah dan kikir. Kedua sifat tercela tersebut sungguh tidak menguntungkan bagi kehidupan manusia, sehingga harus dijauhi dan dihapus dari kehidupan serta menggantinya dengan sifat yang terpuji yaitu sifat melapangkan hati, sabar, merasa senang dan sifat dermawan, murah hati, suka memberi. Agar terhindar dari sifat keluh kesah dan sifat kikir maka seorang muslim dapat melakukannya dengan cara sebagaimana yang dianjurkan dalam Q.S. alMa'arij (70) ayat 19-35 adalah sebagai berikut: mengerjakan shalat pada setiap waktu yang ditetapkan, menunaikan zakat dan mengeluarkan sedekah, beriman kepada adanya hari pembalasan, takut kepada azab Allah swt, memelihara kehormatan, menjaga amanat yang dipercayakan kepadanya, memberikan kesaksian dengan jujur dan adil, dan memelihara shalat dengan baik.
\end{abstract}

Kata Kunci: Konsep Pendidikan Akhlak, Q.S. al-Ma'arij (70) : 19-35

\section{PENDAHULUAN}

Manusia diciptakan oleh Allah swt. belum mengetahui apa-apa baik untuk dirinya sendiri maupun untuk orang lain. Namun, Allah swt. yang Maha Bijaksana tidak menyianyiakan makhluk ciptaan-Nya, maka Allah swt. menurunkan al-Qur'an sebagai pedoman hidup, menuntun kejalan yang benar bagi umat manusia yang memegang tegur ajaranNya. Jadi, fungsi utama al-Qur'an bagi umat manusia adalah untuk menuntun kehidupan mereka ke jalan yang benar sehingga dapat tercapainya kebahagiaan di dunia dan di akhirat kelak. Allah swt. juga memberikan pada diri manusia akal, nurani, dan nafsu. Akal mengajak kita berfikir rasional, nurani mengajak kita untuk melakukan perbuatan baik, sedangkan nafsu biasa mengajak manusia melakukan perbuatan buruk dan melanggar hukum Allah swt. kita harus mengendalikan nafsu melalui kekuatan nurani dan akal. Jika nafsu tidak dikendalikan maka dari kitalah yang akan dikendalikan.

Sesungguhnya nafsu juga merupakan salah satu potensi yang diciptakan Allah swt. dalam diri manusia hingga ia dapat hidup, bersemangat dan lebih kreatif. Dengan demikian maka nafsu sangat penting bagi kehidupan manusia, hanya saja mengingat tabiat nafsu itu berkecenderungan untuk mencari kesenangan, lupa diri, bermalasmalasan yang membawa kesesatan, dan tidak pernah merasa puas maka manusi harus dapat mengendalikannya agar tidak membawa kepada kejahatan (Nur Uhbiyati dan Abu Ahmadi, 1997). 
Sejak awal kehidupan manusia Allah swt. telah memberikan keistimewaan kepada spesies manusia dibandingkan malaikat atau makhluk lainnya . keistimewaan yang pertama, terletak pada pemilikan ilmu, akal, kemauan, ikhtiar, kemampuan membedakan antara yang baik dan buruk. Keistimewaan yang kedua terletak pada asal usulnya, manusia diciptakan dari tanah, air, darah, dan daging. Sebagai implikasinya, manusia memiliki syahwat, naluri, serta hal-hal yang muncul dari naluri tersebut, antara lain berbentuk kebodohan, pertumbuhan darah dan membuat kerusakan di muka bumi, kerugian, kemalasan, keluh kesah lagi kikir, serta tergesa-gesa. Dengan naluriah dan insting manusia secara asasi ingin hidup dan mempertahankan hidup (Kaelany HD, 2000). Sebagaimana dalam firman Allah SWT.

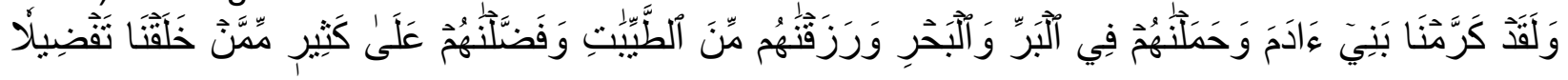
$\checkmark$.

Terjemahan; Dan sesungguhnya telah Kami muliakan anak-anak Adam, Kami angkut mereka di daratan dan di lautan, Kami beri mereka rezeki dari yang baik-baik dan Kami lebihkan mereka dengan kelebihan yang sempurna atas kebanyakan makhluk yang telah Kami ciptakan (QS. Al-Isra [17]:70).

Al-Qur'an memberikan petunjuk dalam persoalan-persoalan aqidah, syari'ah, dan akhlak, dengan jalan meletakkan dasar-dasar prinsipil mengenai persoalan-persoalan tersebut (M. Quraish Shihab, 2009). Pertama, aqidah dan kepercayaan yang harus dianut oleh manusia, yang tersimpul dalam keimanan akan keesaan Allah swt. dan kepercayaaan akan kepastian adanya hari pembalasan. Kedua, mengenai syari'at dan hukum, dengan jalan menerangkan dasar-dasar hukum yang harus diikuti oleh manusia dalam hubungannya dengan Allah swt. dan sesamanya. Ketiga, mengenai akhlak yang murni, dengan jalan menerangkan nurma-nurma keagamaan dan susila yang harus diikuti oleh manusia dalam kehidupannya baik secara individual maupun kolektif (Mohammad Nur Ichwan, 2005).

Islam menghendaki agar orang tua mendidik anaknya dengan akhlak yang baik. Karena akhlak juga merupakan salah satu modal yang sangat pentingan dalam menjalani kehidupan manusia. Berhubungan dengan antar sesame individu, dengan lingkungan, dengan sang pencipta bahkan dengan segala yang maujudpun menggunakan akhlak sebagai modalnya (Nur Uhibuyati, 2009).

Tujuan pendidikan dalam al-Qur'an adalah membina manusia secara pribadi dan kelompok sehingga mampu menjalankan fungsinya sebagai hamba Allah swt dan khalifahnya, guna membangun dunia ini sesuai konsep yang ditetapkan Allah swt.

Manusia merupakan ciptaan Allah swt. yang paling sempurna dari ciptaan-Nya yang lain. Tetapi manusia bukan makhluk ciptaan Allah swt. tanpa cacat, karena Allah swt. juga menciptakan segala perbuatan yang ada (baik dan buruk). Allah swt. lah yang menentukan sesuatu itu baik dan sesuatu yang lain itu tidak baik. Jadi dalam mengukur baik atau buruk, janganlah menurut hawa nafsu melainkan berpedoman pada aturanaturan yang telah Allah swt. ciptakan.

Salah satu cara untuk mencapai akhlak yang baik adalah melalui sistem pendidikan. Pendidikan Islam sebagai suatu usaha atau kegiatan pendidikan sudah barang tertentu dalam prosesnya dan secara sadar diarahkan untuk mencapai tujuan-tujuan pendidikan 
tertentu yang pada gilirannya secara bertahap diharapkan dapat mencapai tujuan akhir pendidikan Islam (Alisuf Sabri, 2005).

Pendidikan Islam adalah suatu proses pengajaran yang mengarah kepada pembentukan akhlak dan kepribadian untuk mencapai produk atau tujuan, baik studi secara teoritis maupun praktis. Sebagaimana kita ketahui bahwa tujuan akhir dalam pendidikan Islam itu terletak pada sikap menyerah diri sepenuhnya kepada Allah swt, baik secara perorangan, masyarakat, maupun sebagai umat manusia keseluruhannya. Sebagai hamba Allah yang berserah diri kepada sang khalik, ia adalah hambanya yang berilmu pengetahuan dan beriman secara bulat, sesuai kehendak sang pencipta untuknya (M. Quraish Sihab, 2008).

Menurut Zakiyah Darajat, tujuan umum pendidikan Islam adalah terbentuknya insan kamil dengan pola taqwa. Insan kamil dengan pola taqwa yang terbentuk dapat mengalami perubahan bertambahnya atau berkurang, karena itu orang yang sudah taqwa dalam bentuk insan kamil masih perlu pendidikan sepanjang hayatnya, guna pengembangan atau peningkatan, paling tidak untuk pemeliharaan sehingga insan kamil yang bertaqwa tersebut akhirnya dapat menghadap Tuhannya (mati) dalam keadaan menjadi muslim paripurna (orang yang berserah diri kepada Allah swt) (Zakiyah Darajat, 1992). Sebagaimana firman Allah SWT.

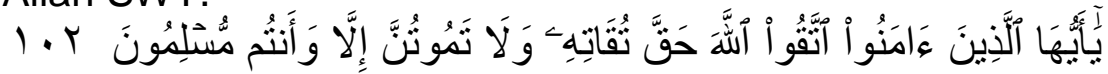

Terjemahan; Hai orang-orang yang beriman, bertakwalah kepada Allah sebenar-benar takwa kepada-Nya; dan janganlah sekali-kali kamu mati melainkan dalam keadaan beragama Islam (QS. Ali Imran [3]: 102).

Al-Qur'an merupakan dasar dari pendidikan Islam. Dengan kata lain semua ajaran Islam yang terkandung dalam al-Qur'an pada akhirnya mengarahkan supaya mendekatkan diri kepada Allah swt. dengan cara berbagai aktifitas yang berguna bagi kehidupan umat manusia pada umumnya. Karena al-Qur'an adalah salah satu dasar dari pendidikan Islam, maka kita selaku umat Islam wajib memahami segala isi yang ada di dalamnya, namun kenyataanya berbeda, tidak sedikit masyarakat yang belum bisa memahami isi kandungan dalam al-Qur'an.

Banyak tafsir yang menafsirkan ayat-ayat al-Qur'an yang ada di dalamnya, salah satu memahami al-Qur'an adalah dengan mengkaji kitab-kitab tafsir. Al-Maraghi adalah salah satu tafsir yang menafsirkan al-Qur'an melalui metode tahlili, dari segi sumber yang digunakan selain menggunakan ayat dan atsar, al-Maraghi juga menggunakan Ra'yi sebagai sumber dalam menafsirkan ayat-ayat al-Qur'an. Dalam surah al-Ma'arij ayat 19 samapai 35 terdapat ayat-ayat yang menjelaskan tentang pendidikan akhlak seorang muslim. Yang termasuk dalam aspek-aspek pendidikan menurut Ahmad D. Marimba bahwa kepribadian muslim itu sendiri adalah kepribadian seorang muslim yang seluruh aspek-aspeknya menunjukan pengabdian kepada Tuhan dan penyerahan diri kepadaNya (Ahmad D. Marimba, 1989). Sebagaimana kita ketahui bahwa ini semua adalah yang dinamakan dengan Akhlak.

Akhlak adalah cerminan keimanan seseorang, iman yang sempurna akan melahirkan akhlak yang mulia. Ibarat sebuah pohon, kekuatan batangnya bergantung pada kekuatan akarnya yang menghunjam kuat ke tanah. Akhlak juga cerminan kemajuan peradaban suatu bangsa atau kaum. Tanpa akhlak, suatu kaum akan terjerumus kedalam lembah kehinaan meskipun mereka Berjaya dalam harta dan benda. Oleh karena itu, Rasulullah saw. pun di utus untuk menyempurnakan akhlak (Handoko, 
dkk, 2004). Pendidikan akhlak adalah jiwa dari pendidikan Islam dan mencapai suatu akhlak yang sempurna adalah tujuan sebenarnya dari pendidikan (M. Athiyah al-Abrasyi, 1987).

Banyak sekali petunjuk dalam agama yang dapat dijadikan sarana untuk memperbaiki akhlak manusia, antara lain anjuran untuk shalat dengan istiqamah, mengingat Allah dimanapun berada, menginfakkan sebagian rizki yang Allah berikan untuk orang yang meminta maupun orang yang tidak meminta, membayar zakat, memiliki kepercayaan akan adanya hari pembalasan, bersabar, bersyukur. Anjuran-anjuran itu, sering didapatkan dalam ayat-ayat akhlak, sebagai nasihat bagi orang-orang yang sering melakukan perbuatan buruk. Allah swt, dalam ayat al-Qur'an menekankan akhlak kepada orang-orang mukmin.

Berdasarkan deskripsi diatas, maka penulis tertarik untuk mengkaji QS al-Ma'arij ayat 19 samapai 35 sekaligus mendeskripsikannya agar dapat menghasilkan karya ilmiah dalam bentuk skripsi. Agar lebih mendetail, maka peneliti fokus dalam karya tersebut dengan judul: Konsep Pendidikan Akhlak dalam Surah al-Ma'arij Ayat 19 Sampai 35. Peneliti memilih Tafsir al-Maraghi sebagai rujukan utama karena menurut peneliti, bahwa tafsir tersebut lebih tepat dan lebih mendalam untuk mengkaji penelitian tersebut.

\section{METODOLOGI PENELITIAN}

\section{Jenis Penelitian}

Jenis penelitian adalah penelitian kepustakaan (Library Research), yaitu membaca dan mengelola semua data dan informasi yang dibutuhkan berasal dari berbagai literatur buku yang berkaitan dengan masalah yang dibahas dan memanfaatkan sumber perpustakaan untuk memperoleh data penelitian (Mestika Zed, 2004). Penelitian ini menganalisis Konsep Pendidikan Akhlak yang terkandung dalam QS. al-Ma'arij ayat 19 sampai 35 dengan menggunakan tafsir al-Maraghi.

\section{Teknik Pengumpulan Data}

Dalam rangka penulisan ini, tentu saja membutuhkan data yang erat kaitannya dengan permasalahan yang akan dibahas. Data dikumpulkan dengan mengunakan metode Library Research (penelitian kepustakaan). Penelitian kepustakaan adalah penelitian yang dilakukan dengan mengutip beberapa sumber dan mempelajari teoriteori para ahli serta buku yang berkaitan dengan obyek yang akan diteliti (M. Natsir, 1988). Data yang digunakan dari kepustakaan diambil dari literatur yang telah diakui kualitasnya.

Untuk memperoleh data-data tersebut digunakan beberapa teknik pengutipan, yaitu:

a. Kutipan langsung yaitu penulis mengutip suatu data yang ada hubunganya dengan pembahasan secara utuh tanpa mengubah sedikutpun redaksi kalimatnya.

b. Kutipan tak langsung, yaitu penulis mengutip suatu data yang berkaitan erat dengan permasalahan dari literatur yang tersedia hanya dalam bentuk inti sarinya, dengan maksud utama yang dikandungnya.

\section{Teknik Analisis Data}

Penelitian ini sifatnya kepustakaan murni, maka metode pengolahan data yang akan diterapkan adalah analisis isi. Di mana analisis isi yang dimaksud adalah sebuah teknik yang digunakan untuk menganalisis dan memahami teks (Sumadi Suryabrata, 2006). 
Adapun analisis makna QS. al-Ma'arij digunakan metode penafsiran tahlili. Di mana tafsir tahlili adalah ilmu tafsir yang menafsirkan ayat-ayat al-qur'an secara berurutan. Namun metode dan analisis lain juga dipergunakan di antaranya metode kualitatif yang dijabarkan melalui teknik-teknik yaitu:

a. Deduktif, yaitu suatu cara atau jalan yang dipakai untuk mendapatkan ilmu pengetahuan ilmiah dengan bertitik tolak dari pertanyaan atau masalah yang bersifat umum kemudian menarik kesimpulan yang bersifat khusus (Sudarto, 1997).

b. Induktif, yaitu suatu cara atau jalan yang digunakan untuk mendapatkan ilmu pengetahuan ilmiah dengan bertitik tolak dari pernyataan atau masalah yang bersifat khusus kemudian ditarik kesimpulan yang bersifat umum (Sudarto, 1997).

c. Komparatif, yaitu penganalisaan data yang dilakukan berdasarkan perbandingan antara data yang satu dengan data yang lain dari masalah yang serupa kemudian diambil suatu kesimpulan yang akan digunakan sebagai pendapat yang baru (M. Natsir, 1988).

Penerapan metode serta ketiga teknik tersebut di atas, meliputi uraian dalam bentuk argumentasi, deskripsi dan analisis. Deskripsi digunakan untuk menggambarkan keadaan obyektif atau materi, tetapi mengambil suatu kesimpulan yang dianggap lebih mewakili suatu kebenaran yang akan diterapkan. Sedangkan argumentsi digunakan untuk menyatakan serta memberi alasan pembuktian untuk memperkuat atau menela'ah suatu pendapat atau gagasan yang terkait dengan obyek pembahasan.

Sistem analisis data tersebut akan digunakan dalam pengolahan data untuk penulisan sehingga memudahkan penulis merampungkan penulisan dan memudahkan menjawab permasalah yang diangkat secara komprehensip sesuai dengan keakuratan data yang diperoleh baik lewat penelitian pustaka.

\section{KAJIAN PUSTAKA}

\section{Pendidikan Akhlak}

Menurut bahasa, "Akhlak" (أَخْاَقُّ) berasal dari bahasa Arab bentuk jama' dari "alKhuluqu" (أَخْقُقُ) yang berarti tabiat, budi pekerti (Ahmad Warsono Munawwir, 2007). Akhlak disamakan dengan perangai, tingkah laku kesusilaan dan sopan santun. Kata akhlak dalam pengertian ini disebutkan dalam al-Qur'an dalam bentuk tunggal. Kata khuluq dalam firman Allah swt. merupakan pembinaan kepada Muhammad saw. sebagai bentuk pengakuan Rasul Allah swt.

Pendidikan akhlak adalah menyucikan diri dari perbuatan akhlak yang buruk, dan berarti pula terdidik atau terpelihara dengan baik, dan berarti pula yang beradap sopan (Abuddin Nata, 2010).

\section{Surah Al-Ma'arij}

Surah al-Ma'arij terdiri dari 44 ayat yang turun pada periode Makkah, yakni sebelum Nabi saw. berhijrah ke Madinah (Quraish Shihab, 2012). Tetapi ada suatu hal istimewa yang disebutkan pada ayat 3 dan 4, yaitu yang bernama al-ma'arij, yang berarti tempat-tempat naik.

Sebagaimana juga surah yang sebelumnya (al-haqqah), maka surah al-ma'arij ini juga dimulai dengan peringatan akan hebatnya apa yang akan terjadi kelak dihari kiamat, terutama kepada orang-orang yang tidak mau mempercayai akan kekuasaan Allah menunggang balikkan alam ini (Tim Sholahuddin, 2015). 


\section{HASIL}

\section{Konsep Pendidikan Akhlak yang terdapat dalam al-Qur'an Surah al-Ma'arij (70)} ayat 19-35

Al-Qur'an menerangkan berbagai ajaran mengenai pendidikan, di dalam Q.S alMa'arij (70): 19-35 terdapat konsep pendidikan akhlak yang dapat menuntun manusia ke jalan yang benar dan menjadikan kehidupannya tenang serta nyaman. Q.S alMa'arij merupakan salah satu dari sekian banyaknya surah didalam al-Qur'an yang membicarakan tentang konsep akhlak, adapun konsep akhlak yang terkandung dalam Q.S al-Ma'arij ayat 19-35 adalah akhlak manusia untuk: Akhlak pada dasarnya melekat dalam diri seseorang, bersatu dengan perilaku atau perbuatan. Jika perilaku yang melekat itu buruk, maka disebut dengan akhlakul Mazmumah. Sebaliknya, apabila perilaku tersebut baik disebut dengan Akhlakul Mahmudah. Akhlak tidak terlepas dari Aqidah dan syariah. Oleh Karena itu, akhlak merupakan pola tingkah laku yang mengakumulasikan aspek kehidupan dan ketaatan sehingga tergambarkan dalam periaku yang baik.

Akhlak merupakan perilaku yang tampak (terlihat) dengan jelas, baik dalam katakata maupun perbuatan yang memotivasi oleh dorongan karena Allah swt. Namun demikian, banyak pula aspek yang berkaitan dengan sikap batin ataupun pikiran seperti akhlak diniyah yang berkaitan dengan berbagai aspek, yaitu pola perilaku kepada Allah, sesame manusia, dan pola perilaku kepada alam.

Akhlak Islami dapat dikatakan sebagai akhlak yang islami adalah akhlak yang bersumber pada ajaran Allah swt. dan Rasulullah saw. Akhlak islami ini merupakan amal perbuatan yang sifatnya terbuka sehingga menjadi indicator seseorang apakah seorang muslim yang baik atau buruk. Akhlak ini merupakan buah dari akidah da syariah yang benar. Secara mendasar, akhlak ini erat kaitannya dengan kejadian manusia yaitu Khaliq (pencipta) dan makhluq (yang diciptakan). Rasulullah saw. diutus untuk menyempurnakan akhlak manusia yaitu untuk memperbaiki hubungan makhluq dengan Makhluq (Syarifah Habibah, 2015).

Al-Qur'an menerangkan berbagai ajaran mengenai pendidikan, di dalam Qs. alMa'arij (70): 19-35 terdapat pendidikan akhlak yang dapat menuntun manusia ke jalan yang benar dan menjadikan kehidupannya tenang serta nyaman. Qs. al-Mar'aij (70): 19-35 merupakan salah satu dari sekian banyaknya surat di dalam al-Qur'an yang membicarakan tentang konsep pendidikan Akhlak, adapun konsep pendidikan akhlak yang terkandung dalam Qs. Al-Ma'raij (70): 19-21 adalah pendidikan akhlak manusia untuk:

a. Melapangkan hati, bersyukur dan jangan berkeluh kesah

Sifat keluh kesah merupakan suatu penyakit yang sangat berbahaya baik bagi ruhani maupun secara psikologi. Penyakit ini bisa timbul karena pengaruh dunia yang penuh dengan ujian dan cobaan. Pada dasarnya manusia memiliki sifat berkeluh kesah, apabila mendapatkan ujian atau cobaan dalam bentuk 
keburukan atau kesulitan, misalnya sepeti musibah, kesulitan atau masalah kehidupan yang lainnya maka manusia akan mudah berkeluh kesah.

Sifat keluh kesah ini melekat pada diri manusia, mulai dari yang miskin sampai yang kaya, mulai dari anak-anak sampai dewasa atau tua. Sifat sepeti ini tidak boleh timbul dan harus dijuahkan dari orang-orang yang beriman dan menggantinya dengan sifat sabar atau berlapang hati, karena setiap ujian kesulitan pasti ada jalan keluarnya. Sebagaimana firman Allah SWT.

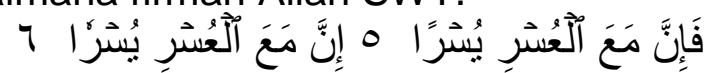

Terjemahan; "Karena Sesungguhnya sesudah kesulitan itu ada kemudahan, Sesungguhnya sesudah kesulitan itu ada kemudahan" (QS. AsySyarh (94): 5-6)

Dan perlu kita fahami bahwa sesungguhnya semua tujuan ujian itu untuk mengukur keimanan seseorang dan mampu meningkatkan kualitas keimanan manusia kepada Allah swt. apabila dapat melewati ujian tersebut dengan baik.

Mengeluarkan sedekah merupakan salah satu bentuk menyucikan harta yang dititipkan Allah kepada kita. Dengan bersedekah harta kita tidak akan berkuang namun sebaliknya, dengan bersedekah maka kan bertambah dan berkembang karena pada hakikatnya Allah akan menambah dan menggantikanya dengan yang lebih baik dan lebih banyak. Hidup akan menjadi indah jika setiap manusia saling berbagi, saling menjaga, saling menyayangi, dan saling memberi karena Allah SWT.

Kedua sifat keluh kesah dan kikir ini merupakan sifat tercela yang dimiliki oleh manusia pada umumnya, sifat sepeti ini harus benar-benar dijauhi oleh orangorang yang beriman. Karena jika kedua sifat ini bersarang pada diri manusia maka akan menimbulkan kedzaliman, permusuhan dan kerusakan dimuka bumi. Sebagaimana firman Allah SWT.:

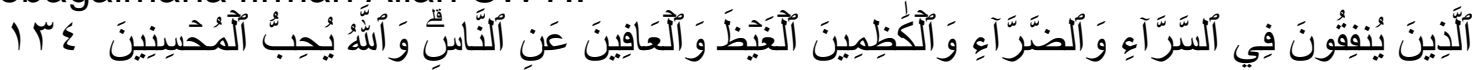

Terjemahan: "(yaitu) orang-orang yang menafkahkan (hartanya), baik di waktu lapang maupun sempit, dan orang-orang yang menahan amarahnya dan mema'afkan (kesalahan) orang. Allah menyukai orang-orang yang berbuat kebajikan". ( QS. Ali-Imran (3): 134).

Rasulullah saw, bersabda dalam Hadits:

"Diriwayatkan dari Abu Hurairah r.a. ada seorang laki-laki datang menemui Rasulullah saw. Dan bertanya, "wahai Rasulullah, sedekah apakah yang paling besar pahalanya? Beliau menjawab, "kamu bersedekah pada waktu sehat dan kiki karena takut fakir dan ingin kaya. Janganlah engkau tunda sedekah hingga ruh telah sampai di tenggorokanmu, lalu engkau beru berkata, "Untuk si fulan sekian, dan si fulan sekian" ingatlah yang itu sudah milik si fulan." (H.R. Muslim).

Dari kedua dalil diatas, maka dapat kita ketahui bahwa agama Islam sangat menganjurkan untuk bersedekah sehingga terhindanya sifat kikir dan berkeluh kesah. dengan bersedekah maka harta yang kita keluarkan dijalan Allah kelak akan Allah ganti dengan yang lebih baik.

Sungguh, Allah swt. telah memberikan Al-Qur'an sebagai pedoman manusia yang lengkap dalam menjalani segala kehidupan di dunia dan akhiat. Maka, 
setelah kita cermati bahwa di dalam Qs. al-Ma'arij (70): 19-21 menerangkan bahwa manusia tersebut pada umumnya memiliki sifat yang tercela yaitu keluh kesah dan kikir yang memang ada pada setiap Individu manusia. Selanjutnya Allah swt. pun memberikan petunjuk cara-cara atau langkah-langkah yang dapat dilakukan agar menghilangkan kedua sifat tersebut yaitu dalam Qs. al-Ma'arij (70): 22-35.

Agama islam merupakan agama yang begitu sempurna ajaran di dalamnya. Al-Qur'an memberikan cara-cara agar terhindar dari sifat keluh kesah dan sifat kikir, maka seorang muslim mengikuti sesuai dengan anjuran yang Allah berikan seperti dalam Qs. al-Ma'arij (70): 22-35, yaitu dengan:

b. Mengerjakan Shalat secara terus menerus pada waktu yang ditetapkan

Kecuali orang-orang yang melaksanakan shalat dengan baik dan benar, sehingga dapat mengalahkan sifat negatif tersebut. Mereka yang tetap melaksanakan shalatnya secara istikhamah (Kementrian Agama RI, 2016). Jika orang benar-benar khusyuk dalam shalatnya, berarti hati dan pikirannya tertuju hanya kepada Allah swt. semata. la merasa berhadapan langsung dengan Allah swt. dalam shalatnya. Timbul dalam hatinya takut karena dosa-dosa yang telah diperbuatnya di samping penuh harap akan limpahan pahala, rahmat, dan karuniaNya. Oleh karena itu, ia berjanji dalam hatinya akan menjauhi dan menghentikan larangan-larangan-Nya. Hatinya pasrah dan tentram menyerahkan diri kepadaNya. Orang yang shalat secara demikian, akan terhindar dari perbuatan keji dan perbuatan mungkar. Kemudian diteruskan bahwa shalat itu selalu dikerjakan pada setiap waktu yang ditentukan, terus-menerus, tidak ada yang lupa dikerjakan walaupun satu shalat, inilah syarat mengerjakan shalat yang dapat menghilangkan kegelisahan ha ti dan kekikiran.

c. Menunaikan zakat dan mengeluarkan sedekah.

Orang-orang yang dalam hartanya yang diraihnya secara halal disispkan bagian tertentu, untuk diserahkan bagi orang miskin yang meminta dan orang miskin yang tidak meminta karena menjaga kehormatannya(Kementrian Agama $\mathrm{RI}, 2016)$. Zakat merupakan salah satu rukun Islam yang wajib ditunaikan oleh setiap muslim apabila telah memenuhi syarat-syarat tertentu.

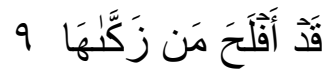

Terjemahan; "Sesungguhnya beruntunglah orang yang mensucikan jiwa itu". (QS. Asy-Syams (91): 9).

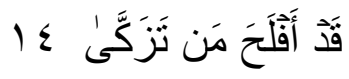

Terjemahan "Sesungguhnya beruntunglah orang yang membersihkan diri (dengan beriman)". (QS. Al-A'la (87): 14).

Melalui ibadah zakat, tujuan pembersihan jiwa dan harta dapat dicapai. Maka amalan berzakat ini mempunyai hubungan langsung dengan kesehatan jiwa.

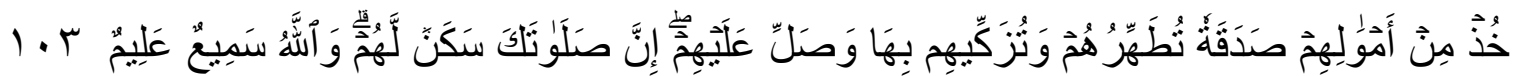

Terjemahan:"Ambillah zakat dari sebagian harta mereka, dengan zakat itu kamu membersihkan dan mensucikan mereka dan mendoalah untuk 
mereka. Sesungguhnya doa kamu itu (menjadi) ketenteraman jiwa bagi mereka. dan Allah Maha mendengar lagi Maha mengetahui". (QS. At-Taubah (9): 103).

Berhubungan dengan keshatan jiwa, melalui amalan zakat dan sedekah dapat membentuk jiwa yang insan, smpati dan suka menolong sesama manusia. Sifat-sifat mulia ini merupakan antara ciri-ciri yang dimaksudkan sebagai bersosialisasi dengan orang lain.

d. Beriman atau meyakini akan adanya hari pembalasan.

Dalam ayat 26 , Allah swt. menyatakan seterusnya bahwa orang yang tidak akan tertimpa sakit resah dan gelisah adalah orang-orang yang mempercaai hari pembalasan. Ibnu katsir menyatakan bahwa orang yang meyakini hari kebangkitan, hisab dan pembalasan, mereka adalah orang yang mengerjakan amal orang-orag yang mengharapkan pahal dan takut dengan hukuman Allah swt.

Hari kiamat juga disebut sebagai hari perhitungan dan hari pembalasan. Pada hari kiamat, manusia akan mendapatkan keadilan dengan diberi ganjaran kepada kebaikan yang dibuat dan mendapatkan hukuman atas kejahatan yang dilakukan. Rasulullah saw. bersabda:

"Siapa saja yang beriman kepada Allah dan hari Akhir, maka dia perlu berkata perkara yang baik atau diam saja. Siapa saja yang beriman kepada Alah swt. dan hari Akhir, maka ia perlu memuliakan tetangganya. Siapa saja yang beriman kepada Allah swt. dan hari Akhir, maka ia perlu memuliakan tamunya." (HR. Bukhari dan Muslim).

Tujuan utama Allah swt. membangkitkan manusia pada hari kiamat adalah untuk menghitung dosa dan pahala mereka hasil dari perbuatan mereka ketika berada di dunia. Balasan baik dan buruk itu menunjukan bahwa manusia tidak diciptakan dengan sia-sia tanpa ada tujuan tertentu. Sedangkan Allah swt. telah menjelaskan bahwa tujuan manusia diciptakan adalah untuk beribadah kepadanya. Maka, segala balasan yang dijanjikan ini dapat ditunaikan dengan adanya hari kiamat.

Orang yang beriman kepada hari kiamat juga mendapat ketenangan jiwa yang tidak mungkin diperoleh oleh mereka yang tidak beriman. Keimanan terhadap kehidupan di akhirat adalah kekal abadi dan lebih baik berbanding dengan kehidupan di dunia yang penuh dengan penindasan dan ketidak adilan. Oleh karena itu islam sangat mengarahkan umatnya agar berlomba-lomba dalam melakukan kebaikan sebagai bekal untuk diakhirat nanti. Sebagaimana dalam firman Allah SWT:

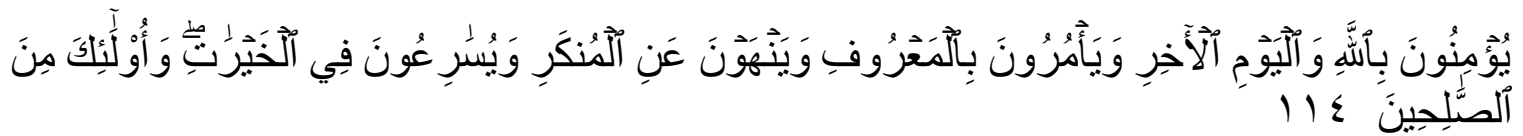

Terjemahan "Mereka beriman kepada Allah dan hari penghabisan, mereka menyuruh kepada yang ma'ruf, dan mencegah dari yang Munkar dan bersegera kepada (mengerjakan) pelbagai kebajikan; mereka itu Termasuk orang-orang yang saleh". (QS. Ali-Imran (3): 114). 


\section{e. Takut terhadap Azab Allah}

Allah SWT. menyebutkan orang yang takut kepada azabNya dengan menjauhkan diri dari melakukan perkara yang murkai Allah. Menurut Ibnu Katsir, bahwa mereka adalah orang yang takut dan khawatir terhadap Azab Allah yang jika sesiapa menerimanya, dia tidak akan mendapakan keamanan kecuali keamanan yang diberikan oleh Allah SWT.

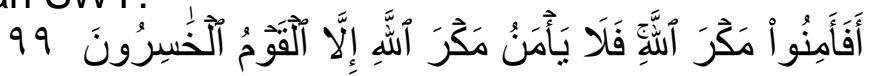

Terjemahan: "Maka Apakah mereka merasa aman dari azab Allah (yang tidak terduga-duga)? tiada yang merasa aman dan azab Allah kecuali orang-orang yang merugi". (QS. Al-A'raf (7): 99).

Ayat ini menyatakan bahwa mereka adalah orang yang di dunia takut ditimpakan oleh azab Allah swt. ketika di akhirat nanti. penyakit keluh dan kesah tidak akan menimpa orang yang takut kepada azab Allah swt. karena mereka tau bahwa azab Allah swt. tiada sesiapa yang merasa aman dari kedatangannya. Oleh karena itu setiap muslim harus takut terhadap azab Allah swt.

Dalam ayat ini bahwa tidak satupun diantara manusia yang merasa dirinya aman dari kedatangan azab Allah swt. Oleh karena itu, ia berusaha menjauhi azab tersebut dengan bertaqwa kepada Allah swt. Orang-orang yang benar-benar beriman maka akan selalu mendirikan shalat wajib, menunaikan zakat, dan percaya terhadap hari akhir, hari dimana dilaksanakannya keadilan yang sesungguhnya.

f. Memelihara kehormatan

Golongan yang terhindar dari penyakit keluh kesah adalah mereka yang menjaga kemaluannya kecuali terhadap istri dan hamba perempuan. Penyakit keluh kesah atau jiwa tidak tenang ini boleh berlaku kepada pelaku-pelaku zina. Ini karena zina termasuk dalam kategori dosa besar. Allah swt. telah menyatakan bahwa pelaku zina termasuk golongan yang kotor dan jahat. Dan pezina laki-laki hanya boleh menikahi pezina wanita atau wanita musyrik. Keadaan ini menunjukan bahwa berbuat zina merupakan perbuatan yang sangat keji dan menjijikan.

Dan orang-orang yang memelihara kemaluannya secara mantap dan sungguh-sungguh, kecuali terhadap istri-istri pasangan-pasangan mereka yang sah menurut agama, atau hamba sahaya yang mereka miliki maka sesungguhnya mereka tidak tercela selama mereka lakukan tidak melarang ketentuan agama. Maka barang siapa mencari pelampiasan hawa nafsunya di luar itu seperti zina, homoseks, dan lesbian, mereka itulah orang-orang yang melampaui batas ajaran agama dan moral, maka wajar dicela dan disiksa (Kementrian Agama RI, 2016).

Dalam tafsir al-Azhar ayat 29, faraj diartikan sebagai kemaluan, bias juga diartikan sebagai kehormatan. Artinya yang lebih tepat adalah alat kelamin lakilaki dan alat kelamin perempuan. Dalam ayat ini disebut bahwa salah satu ciri tanda orang yang beriman adalah yang menjaga dan tidak mempergunakan alat kelaminya dengan salah satu atau tidak menjaga dan memeliharanya (Hamka, 2015). 
Oleh sebab itu, Allah swt. menghalang orang islam dari menghampiri perkara-perkara yang membawa kepada perlakuan zina, apalagi melakukannya. Zina adalah satu perbuatan yang keji, jahat dan membawa kepada kerusakan pada manusia.

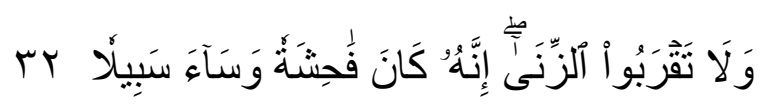

Terjemahan: "Dan janganlah kamu mendekati zina; Sesungguhnya zina itu adalah suatu perbuatan yang keji. dan suatu jalan yang buruk". (QS. Al-Isra (17): 32).

g. Memelihara amanat dan janji

Amanah dan janji adalah setiap apa yang dipertanggung jawabkan kepada seseorang hamba yang berkaitan perkara dunia dan agama, sama halnya dalam bentuk percakapan atau perbuatan. Walaupun amanah lebih umum dari pada janji, namun setiap janji adalah amanah.

Lawan dari sifat amanah adalah bohong, menipu dan mengingkari janji. Khianat dan mengingkar janji merupakan salah satu dari ciri-ciri orang munafik. Sifat khianat atau tidak amanah juga termasuk dalam dosa besar, ini karena Allah swt. tidak suka kepada perbuatan khianat sedangkan Allah swt amat mengetahui pengkhianatan yang dilakukan walaupun ia tersembunyi di dalam hati manusia.

Ibnu katsir, meriwayatkan kisah seorang sahabat Nabi saw. yang telah berlaku khianat terhadap urusan yang diamanahkan oleh Rasulullah saw. Sahabat ini telah bertaubat kepada Allah dan Rasulnya. Dan Allah swt. menerima taubatnya selepas sembilan hari. Sepanjang hari itu, sahabat telah mengalami keadaan keluh kesah, kerisauan dan tekanan yang mendalam.

Kisah ini memberikan pelajaran bahwa kemurkaan Allah swt. dan Rasul saw. menyebabkan keadaan yang sangat tidak tentram, keluh kesah dan tekanan. Justru ituperbuatan mengingkari janji adalah satu tindakan yang mengundang dosa dan tekanan jiwa yang perlu dijauhi. Sebagaimana, yang disebutkan di dalam sebuah hadist sahih yang mengatakan:

"Pertanda orang munafik itu ada tiga, yaitu apabila berbicara dia dusta, apabila dia berjanji dia menginkari dan apabila dipercaya dia khianat" (Al-Imam Ismail Ibnu Kasir Ad-Dimasyqi, 2010).

h. Memberikan kesaksiaan dengan jujur dan adil

Selanjutnya Allah swt. menegaskan bahwa golongan yang tidak ditimpa penyakit keluh kesah adalah mereka yang memberikan kesaksian yang benar. Berkaitan dengan keluh kesah dan saksi yang adil, orang yang berbohong dalam penyaksiannya akan berhadapan dengan situasi dimana dia terpaksa menerkanerka maklumat atau cerita dalam usaha ingin menyembunyikan maklumat yang dimilikinya. Dalam keadaan ini ia tidak dapat ketenangan, jiwanya sentiasa resah gelisah karena berbohong atau menyembunyikan sesuatu.

Selain itu, rasa bersalah juga menghantui orang yang berbohong apabila sesorang itu menyembunyikan fakta dalam penyaksiannya yang menyebabkan orang yang berhak tidak mendapatkan haknya atau pembelaan sewajarnya. 
Sebaliknya, jika dia berkata benar dalam penyaksian, dia sebenarnya membantu hakim dan orang ramai dalam mendapatkan keadilan dan mengembalikan hak kepada empunya hak. Dalam tafsir mereka juga orang-orang yang berpegang teguh dengan sungguh-sungguh kepada kesaksiannya, tanpa dipengaruhi oleh kepentingan diri, keluarga atau kelompok (Kementrian Agama RI, 2016).

i. Memelihara shalat dengan baik

Golongan terakhir yang akan dihindari penyakit keluh kesah adalah orang yang senantiasa menjaga shalatnya. Ibnu katsir menjelsakan bahwa orang-orang yang menjaga shalat itu adalah orang yang menjaga waktu, rukun, perkaraperkara wajib dan perkara-perkara sunnah dalam shalat. Sebagai balasan, Allah swt. menjanjikan mereka akan kekal hidup di dalam syurga yang mulia.

Allah swt. menyebutkan golongan pertama yang terhindar daripada penyakit keluh kesah adalah orang yang menunaikan shalat. Manakala golongan kedelapan adalah orang yang menjaga shalat. Pada golongan pertama, Allah swt. menyebutkan sifat mereka dengan senantiasa mengerjakan shalat (daimun), sedangkan pada golongan kedelapan Allah menyebutka dengan sifat "memelihara shalat" (yuhafidzun).

Dan orang-orang yang memelihara shalatnya, baik menyangkut waktu pelaksanaannya, syarat, rukun wajibnya serta sunah-sunahnya(Kementrian Agama RI, 2016). Ayat ini menerangkan selain yang telah disebutkan, masih ada satu hal lagi yang dapat menghilangkan sifat berkeluh kesah dan kikir, yaitu selalu memelihara shalat.

Dengan melaksanakan semua cara-cara di atas, maka akan dengan mudah menghapus sifat keluh kesah dan sifat kikir. Serta dengan menggantinya dengan sifat melapangkan hati, sabar dan sifat dermawan dan mudah-mudaham akan mendapat balasan surga di akhirat kelak dari Allah swt.

Konsep pendidikan akhlak yang terkandung dalam QS. al-Ma'arij (70) ayat 19-35 adalah kita harus berpegang teguh terhadap tauhid, al-qur'an dan hadist dan juga kita harus menjauhi sifat tercela yang umum dimiliki oleh manusia yaitu sifat keluh kesah dan kikir. Kedua sifat tercela tersebut sungguh tidak menguntungkan bagi kehidupan manusia, sehingga harus dijauhi dan dihapus dari kehidupan serta menggantinya dengan sifat yang terpuji yaitu sifat melapangkan hati, sabar, merasa senang dan sifat dermawan, murah hati, suka memberi. . Agar terhindar dari sifat keluh kesah dan sifat kikir maka seorang muslim dapat melakukannya dengan cara sebagaimana yang dianjurkan dalam Q.S. al-Ma'arij (70) ayat 19-35 adalah sebagai berikut: mengerjakan shalat pada setiap waktu yang ditetapkan, menunaikan zakat dan mengeluarkan sedekah, beriman kepada adanya hari pembalasan, takut kepada azab Allah swt, memelihara kehormatan, menjaga amanat yang dipercayakan kepadanya, memberikan kesaksian dengan

\section{PENUTUP} jujur dan adil, dan memelihara shalat dengan baik.

Sesuai dengan uraian-uraian pada bab-bab sebelumnya maka dikemukakan sebuah kesimpulan yaitu: konsep pendidikan akhlak yang terdapat pada surah al-Ma'arij ayat 19 sampai ayat 35 terdiri dari tiga aspek penting yaitu tauhid, al-qur'an dan hadist dengan aspek antara lain yaitu kita harus menjauhi sifat tercela yang umum dimiliki oleh 
manusia yaitu sifat keluh kesah dan kikir. Kedua sifat tercela tersebut sungguh tidak menguntungkan bagi kehidupan manusia, sehingga harus dijauhi dan dihapus dari kehidupan serta menggantinya dengan sifat yang terpuji yaitu sifat melapangkan hati, sabar, merasa senang dan sifat dermawan, murah hati, suka memberi. Agar terhindar dari sifat keluh kesah dan sifat kikir maka seorang muslim dapat melakukannya dengan cara sebagaimana yang dianjurkan dalam Q.S. al-Ma'arij (70) ayat 19-35 adalah sebagai berikut: mengerjakan shalat pada setiap waktu yang ditetapkan, menunaikan zakat dan mengeluarkan sedekah, beriman kepada adanya hari pembalasan, takut kepada azab Allah swt, memelihara kehormatan, menjaga amanat yang dipercayakan kepadanya, memberikan kesaksian dengan jujur dan adil, dan memelihara shalat dengan baik.

\section{DAFTAR PUSTAKA}

[1] Al-Qur'an Al-Karim

[2] Abu Ahmadi, Nur Uhbiyati. IImu Pendidikan Islam, Bandung: Pustaka Setia, 1997.

[3] Ahmad D. Marimba, Pengantar Filsafat Pendidikan Islam, Bandung: al-Ma'arif, 1989.

[4] Athiyah al-Abrasyi, M. Dasar-Dasar Pokok Pendidikan Islam, Terjemahan Bustami A Gani dan Djohar Bahry, Cet. V; Jakarta:Bulan Bintang, 1987.

[5] Darajat, Zakiyah. IImu Pendidikan Islam, Jakarta: Bumi Aksara, 1992.

[6] Departemen Agama RI, Al-Qur'an dan Terjemahnya, Jakarta: PT Sygma Examedia Arkanleema, 2009.

[7] Hamka, Tafsir Al-Azhar; Diperkaya Dengan Pendekatan Sejarah, Sosiologi, Tasawuf, Ilmu Kalam, Sastra, Dan Psikologi. Jakarta; Gema Insani: 2015.

[8] Handoko, dkk, Meneladani Akhlak, Jakarta, 2004.

[9] Ibnu Kasir Ad-Dimasyqi, Al-Imam Ismail. Tafsir Ibnu Katsir, Al-Mulk Sampai Dengan Al-Mursalat, Juz 29, Cet. III; Bandung: Sinar Baru Algensindo, 2010.

[10] Kaelany HD, Islam dan Aspek-Aspek Kemasyarakatan, Jakarta: Bumi Aksara, 2000.

[11] Kementrian Agama RI, Tafsir Ringkas Al-Qur'an Al-Karim, Cet. I; Jakarta: Lajnah Pentashihan Mushaf Al-Qur'an, Tahun 2016.

[12] Munawwir, Ahmad Warsono. Kamus Arab-Indonesia, Cet.l; Surabaya: Pustaka Progresif, 2007.

[13] Nata, Abuddin. Ilmu Pendidikan Islam, Jakarta:Kencana Prenada Media Group,2010.

[14] Natsir, M. Metode Penelitian, Cet. IV; Jakarta: Galia Indonesia, 1988.

[15] Nur Ichwan, Mohammad. Belajar Al-Qur'an: Menyingkap Khazanah IImu-IImu alQur'an Melalui Pendekatan Historis-Metodologis, Semarang: Rasail, 2005.

[16] Quraish Shihab, Al-Lubab ; Makna, Tujuan, dan Pelajaran Dari Surah-Surah AlQur’an, Tanggerang: Lentera Hati, 2012.

[17] Quraish Shihab, M. Membumikan Al-Qur'an Fungsi dan Peran Wahyu dalam Kehidupan Masyarakat, Bandung: PT Mizan Pustaka, 2009.

[18] Quraish Sihab, M. Wawasan Al-Qur'an, Bandung: Mizan Pustaka, 2007.

[19] Sabri, Alisuf Pengantar IImu Pendidikan, Jakarta: UIN Jakarta Press, 2005.

[20] Sudarto, Metode Penelitian Filsafat, Cet. II; Jakarta: Grafindo Persada, 1997.

[21] Suryabrata, Sumadi. Metodologi Penelitian, Jakarta: PT Raja Grafindo Persada, 2006. 
[22] Tim Sholahuddin, Kumpulan Juz 30, 29, dan 28; Al-Matsurat Hadist Arbain. Jakarta: Sholahuddin Perss, 2015.

[23] Uhibuyati, Nur Long Life Education: Pendidikan Anak Sejak dalam Kandungan sampai Lansia, Semarang: Walisongo Press, 2009.

[25] Zed, Mestika. Metode Penelitian kepustakaan, Cet:I:Jakarta:Yayasan Obor Indonesia,2004. 